\title{
The Murid Herpesvirus-4 $\mathrm{gH} / \mathrm{gL}$ Binds to Glycosaminoglycans
}

\author{
Laurent Gillet ${ }^{\text {, }}$ Susanna Colaco, Philip G. Stevenson* \\ Division of Virology, Department of Pathology, University of Cambridge, Cambridge, United Kingdom
}

\begin{abstract}
The first contact a virus makes with cells is an important determinant of its tropism. Murid Herpesvirus-4 (MuHV-4) is highly dependent on glycosaminoglycans (GAGs) for cell binding. Its first contact is therefore likely to involve a GAG-binding virion glycoprotein. We have previously identified two such proteins, gp70 and gp150. Gp70 binds strongly to GAGs. However, deleting it makes little difference to MuHV-4 cell binding or GAG-dependence. Deleting gp150, by contrast, frees MuHV-4 from GAG dependence. This implies that GAGs normally displace gp150 to allow GAG-independent cell binding. But the gp150 GAG interaction is weak, and so would seem unlikely to make an effective first contact. Since neither gp70 nor gp150 matches the expected profile of a first contact glycoprotein, our understanding of MuHV-4 GAG interactions must be incomplete. Here we relate the seemingly disconnected gp70 and gp150 GAG interactions by showing that the MuHV-4 gH/ $\mathrm{gL}$ also binds to GAGs. $\mathrm{gH} / \mathrm{gL}$-blocking and gp70-blocking antibodies individually had little effect on cell binding, but together were strongly inhibitory. Thus, there was redundancy in GAG binding between gp70 and gH/gL. Gp150-deficient MuHV-4 largely resisted blocks to gp70 and gH/gL binding, consistent with its GAG independence. The failure of wild-type MuHV-4 to do the same argues that gp150 is normally engaged only down-stream of gp70 or gH/gL. MuHV-4 GAG dependence is consequently two-fold: $\mathrm{gp} 70$ or $\mathrm{gH} / \mathrm{gL}$ binding provides virions with a vital first foothold, and gp150 is then engaged to reveal GAG-independent binding.
\end{abstract}

Citation: Gillet L, Colaco S, Stevenson PG (2008) The Murid Herpesvirus-4 gH/gL Binds to Glycosaminoglycans. PLoS ONE 3(2): e1669. doi:10.1371/ journal.pone.0001669

Editor: Peter Sommer, Institut Pasteur Korea, Republic of Korea

Received December 21, 2007; Accepted January 22, 2008; Published February 27, 2008

Copyright: (c) 2008 Gillet et al. This is an open-access article distributed under the terms of the Creative Commons Attribution License, which permits unrestricted use, distribution, and reproduction in any medium, provided the original author and source are credited.

Funding: Laurent Gillet is a Postdoctoral Researcher of the Fonds National Belge de la Recherche Scientifique (FNRS). Philip Stevenson is a Wellcome Trust Senior Clinical Fellow (GR076956MA). This work was also supported by Medical Research Council grants G0400427 and G9800903 and by Cancer Research UK grant C19612/A6189.

Competing Interests: The authors have declared that no competing interests exist.

*E-mail: pgs27@cam.ac.uk

a Current address: Immunology-Vaccinology, Faculty of Veterinary Medicine, University of Liège, Liège, Belgium

\section{Introduction}

Many herpesviruses use glycosaminoglycans (GAGs) for their first cell contact. Murid Herpesvirus-4 (MuHV-4) is highly dependent on GAGs for cell binding and infection [1]. Its ORF4 encodes a strong GAG-binding virion glycoprotein, gp70 [2], which is homologous to the Kaposi's Sarcoma-associated Herpesvirus ORF4 gene product [3], and analogous to the Herpes Simplex virus gC [4]: all are complement control proteins that also bind to GAGs [5]. But if a need for GAG binding by gp70 explained MuHV-4 GAGdependence, then gp70-deficient MuHV-4 should bind poorly to $\mathrm{GAG}^{+}$cells, much as the wild-type binds poorly to $\mathrm{GAG}^{-}$cells [6]. Instead, gp70-deficient MuHV-4 shows little deficit in binding or infection, and is if anything better inhibited by soluble heparin than the wild-type [2]. Also, much of the gp70 on MuHV-4 virions is posttranslationally cleaved to release its GAG-binding domain [2]. These data suggest that gp70 does not provide a particularly important first contact. It might be more important for saturating the GAGs on productively infected cells to promote virion release, or for absorbing soluble GAGs in infectious foci to stop them inhibiting spread. Alternatively, its GAG binding might be subservient to complement evasion [7].

While the contribution gp70 makes to MuHV-4 GAGdependence is unclear, there is good evidence for the MuHV-4 gp150 being important [1]. Thus, gp150-specific monoclonal antibodies (mAbs) increase MuHV-4 infection of GAG-deficient

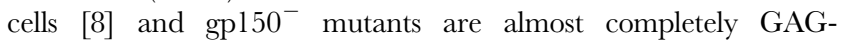
independent: they infect $\mathrm{GAG}^{+}$cells normally, infect $\mathrm{GAG}^{-}$cells much better than the wild-type does, and largely resist inhibition by soluble heparin. Interestingly, the gp150 homolog of Epstein-Barr virus (EBV), gp350, has a similar inhibitory role in making EBV infection CD21-dependent [9,10]. But unlike the strong CD21 binding of gp350 [11], recombinant gp150 binds to GAGs at best weakly [2]. This argues against gp150 being important for the initial capture of virions onto cell surfaces. Also, gp150 knockouts generally bind better to cells rather than worse. Thus, gp150 is not so much a cell binding protein as a GAG-sensitive switch, constitutively inhibiting MuHV-4 infection until GAGs are engaged.

The combination of an abundantly secreted protein that binds GAGs strongly (gp70) and a regulatory protein that binds GAGs weakly (gp 150) makes sense as a virion release mechanism. However, it leaves unanswered how MuHV-4 virions first attach to cells: neither gp70 nor gp150 fits the expected profile of a strong cell binding protein for which the corresponding knockout virus shows a marked binding deficit. MuHV-4 has at least 2 more cell-binding virion glycoproteins that could contribute: $\mathrm{gB}$, which binds to cells as an Fc fusion protein [2]; and gL, since gL-deficient mutants binding less well than the wild-type to adherent cells $[6,12]$. Because $\mathrm{gB}$ binds to a non-GAG ligand [2], while the MuHV-4 first contact is very likely to involve GAGs, we focussed here on gL. 
gL lacks a membrane anchor and resides in the virion envelope by virtue of its association with $\mathrm{gH}$ [13]. As with other herpesviruses [14,15], the presence or absence of gL sets the MuHV-4 gH conformation [12,13]. Interestingly, glycosyl-phosphatidyl-inositol (GPI)-linked gL still folds gH into its native virion form [13]. gL is therefore likely to lie close to the virion membrane in the mature $\mathrm{gH} / \mathrm{gL}$ heterodimer. This, and the small size of $\mathrm{gL}$, argue that $\mathrm{gL}$ does not bind to cells itself, but rather operates through its effect on $\mathrm{gH}$. In order to understand better how $\mathrm{gH} /$ gL, gp70, gp150 and gB work together, and how gL might contribute to virion capture, we expressed recombinant $\mathrm{gH} / \mathrm{gL}$ and tested it for cell binding. We found that $\mathrm{gH} / \mathrm{gL}$, like gp70, binds to GAGs. gH alone did not, explaining why a gL deficiency reduces MuHV-4 binding to adherent cells. GAG binding by gH/ $\mathrm{gL}$ also explains the redundancy of gp70. In a refined model, we propose that MuHV-4 first engages cells through either $\mathrm{gH} / \mathrm{gL}$ or gp70 binding GAGs. Gp150 displacement then allows GAGindependent cell binding, probably by $\mathrm{gB}$.

\section{Results}

\section{GAG binding by recombinant $\mathrm{gH} / \mathrm{gL}$}

We first attempted to make a soluble MuHV-4 $\mathrm{gH} / \mathrm{gL}$ heterodimer by co-expressing an $\mathrm{Fc}_{\mathrm{c}}$ fusion of the $\mathrm{gH}$ extracellular domain with $\mathrm{gL}$, as done for Herpes simplex virus [16]. This failed. We have previously observed that although $\mathrm{gL}$ is bound to $\mathrm{gH}$ in virions, the transfected $\mathrm{MuHV}-4 \mathrm{gL}$ folds GPI-linked $\mathrm{gH}$ poorly [13]. $\mathrm{gH}$ and $\mathrm{gL}$ associate in the endoplasmic reticulum of infected cells, as pulse-labelled, endoglycosidase $\mathrm{H}$-sensitive $\mathrm{gH}$ displays $\mathrm{gH} / \mathrm{gL}$ epitopes [13]. But whereas the Herpes simplex virus $\mathrm{gH}$ is retained in the endoplasmic reticulum without $\mathrm{gL}$ [14], the MuHV-4 gH is exported [13]. Other MuHV-4 glycoproteins may therefore be needed to keep gH and gL together. Notably, virion $\mathrm{gH} / \mathrm{gL}$ is normally associated with $\mathrm{gB}$ and probably also with gp150 [6].

In contrast to soluble gL, GPI-linked gL folds gH-GPI quite well [13]. This applied also to $\mathrm{gH}$ with its native transmembrane domain (Fig. 1A). Some gL immobilization may therefore suffice to stabilize $\mathrm{gH} / \mathrm{gL}$. We have previously made a membrane-bound form of $\mathrm{gH} / \mathrm{gL}$ by fusing GPI-linked $\mathrm{gL}$ to the $\mathrm{gH}$ extracellular domain [17]. This construct reconstituted the epitopes of $42 / 42$ $\mathrm{gH} / \mathrm{gL}$-specific mAbs, all derived from infected mice and specific for conformational epitopes displayed on infected cells (data not shown). We reasoned that a $\mathrm{gH}-\mathrm{gL}$ fusion protein reproduces the native $\mathrm{gH} / \mathrm{gL}$ extracellular domain, and so used the same approach to make soluble $\mathrm{gH} / \mathrm{gL}$.

Flow cytometry established that a gH-gL-Fc fusion (gHL-Fc) reached the plasma membrane of transfected cells and reproduced native $\mathrm{gH} / \mathrm{gL}$ epitopes (Fig. 1B). gHL-Fc but not gH-Fc recovered from transfected cell supernatants bound to BHK-21 cells (Fig. 2A). Other Fc fusion proteins are shown for comparison. Expression levels for each are shown in Fig. 2B. Gp70-SCR12-Fc incorporates the gp70 GAG-binding domain [2]. gB-N-Fc incorporates the N-terminal MuHV-4 gB furin cleavage product [18], equivalent to domains $\mathrm{I}$ and II of the Herpes simplex virus $\mathrm{gB}$ [19]. Both bound to BHK-21 cells. The N-terminal third of gp 150 fused to GST can bind to GAGs at high dose [2], but neither the same portion of gp150 nor the full-length extracellular domain (shown here) did so when fused to IgG Fc, presumably because gp150 binds to GAGs with very low affinity. Neither gp70SCR12-Fc nor gHL-Fc bound to GAG-deficient CHO cells, and both had their binding to $\mathrm{GAG}^{+} \mathrm{CHO}$ cells blocked by preincubation with soluble heparin (Fig. 2C). Both therefore depended on GAGs for binding.
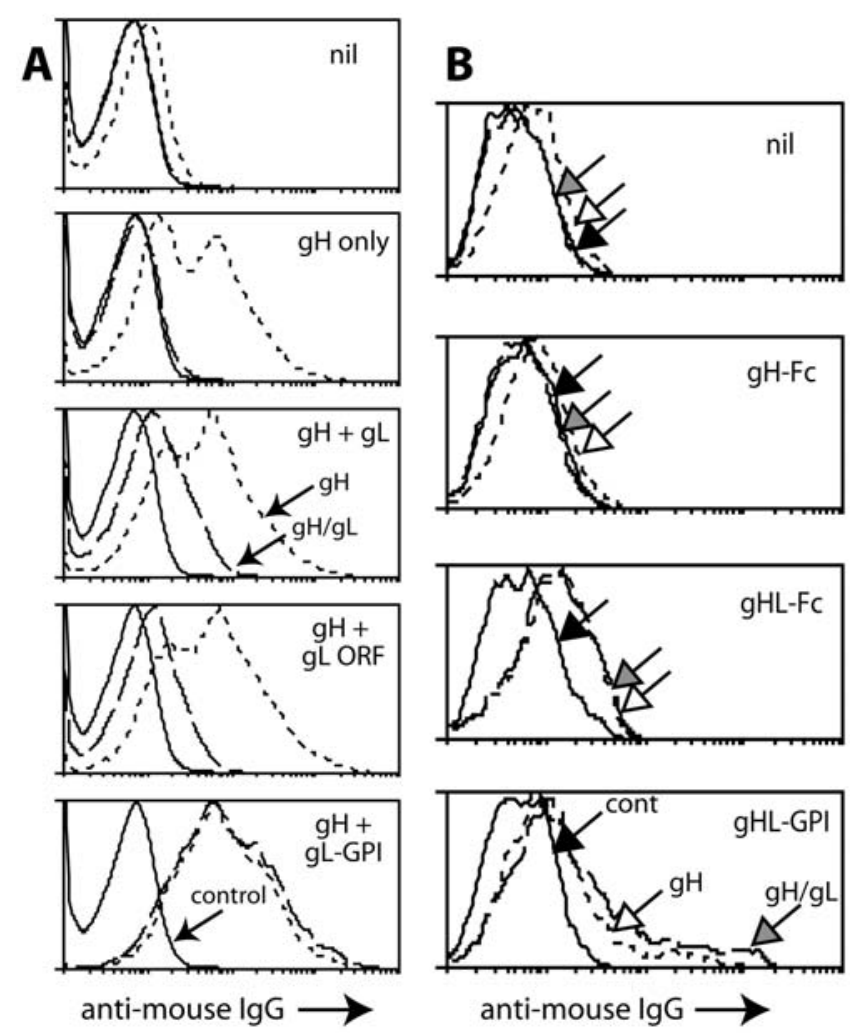

Figure 1. Expression of $\mathbf{g H} / \mathbf{g L}$ as a single $\mathrm{Fc}$ fusion protein. A. 293T cells were transfected with different expression plasmids. 48h later they were trypsinized and analyzed by flow cytometry for expression of $\mathrm{gH}$ with $\mathrm{mAb} 8 \mathrm{C} 1$ (short dashes) or $\mathrm{gH} / \mathrm{gL}$ with $\mathrm{mAb} 7 \mathrm{E} 5$ (long dashes). Control = secondary antibody only (solid lines). "gH+gL ORF" used the full-length genomic ORF47; " $\mathrm{gH}+\mathrm{gL}$ " used the RACE-mapped $\mathrm{gL}$, which starts at the 5th in-frame ORF47 AUG codon [9]; "gH+gL-GPI" used a GPI-linked form of the RACE-mapped $\mathrm{gL}$. In each case, $\mathrm{gH}$ was expressed from the full-length genomic ORF22. nil=untransfected. B. 293T cells were transfected with diferent $\mathrm{gH}$ expression plasmids or left untransfected (nil), and $48 \mathrm{~h}$ later analyzed for $\mathrm{gH}$ expression with $\mathrm{mAb}$ $8 \mathrm{C} 1$ (short dashes, white arrow) and for $\mathrm{gH} / \mathrm{gL}$ expresion with mAb 7E5 (long dashes, grey arrow), as in A. Solid lines/black arrow = secondary antibody only. gHL-GPI and gHL-Fc are the same fusion protein with either a C-terminal GPI anchor or human $\operatorname{lgG}_{1}-\mathrm{Fc}$. Each histogram shows 10,000 cells. Both $\mathrm{gH}$-specific and $\mathrm{gH} / \mathrm{gL}$-specific staining was significantly increased after gHL-Fc transfection compared with controls $(p<0.00001$ by Student's $t$ test). Equivalent results were obtained in a repeat experiment.

doi:10.1371/journal.pone.0001669.g001

\section{$\mathrm{gH} / \mathrm{gL}$ precipitation from virion lysates by heparin- agarose}

We previously failed to identify $\mathrm{gH} / \mathrm{gL}$ by precipitating virion proteins with heparin-agarose [2]. Two factors probably contributed. First, we have no antibody that immunoblots gH, making it harder to detect than $\mathrm{gB}$, gp150 or gp70. Second, we used Triton X100 virion lysates. Fig. 1 suggests that the MuHV-4 gH and gL do not form a stable heterodimer without other virion proteins. $\mathrm{gB}$ may be one, since it associates with $\mathrm{gH} / \mathrm{gL}$ and hides parts of it from antibody [20]. The $\mathrm{gH} / \mathrm{gL} / \mathrm{gB}$ association is preserved in digitonin but lost in Triton X-100 [6]. Thus, gB dissociation in Triton X-100 may destabilize $\mathrm{gH} / \mathrm{gL}$. We have immunoprecipitated $\mathrm{gH} / \mathrm{gL}$ from Triton X-100 virion lysates with $\mathrm{gH} / \mathrm{gL}$-specific mAbs [12]. But $\mathrm{mAb}$ binding would provide considerable extra stability; heparinagarose binding may not. We therefore tested heparin-agarose for $\mathrm{gH} / \mathrm{gL}$ precipitation using digitonin virion lysates (Fig. 3). 

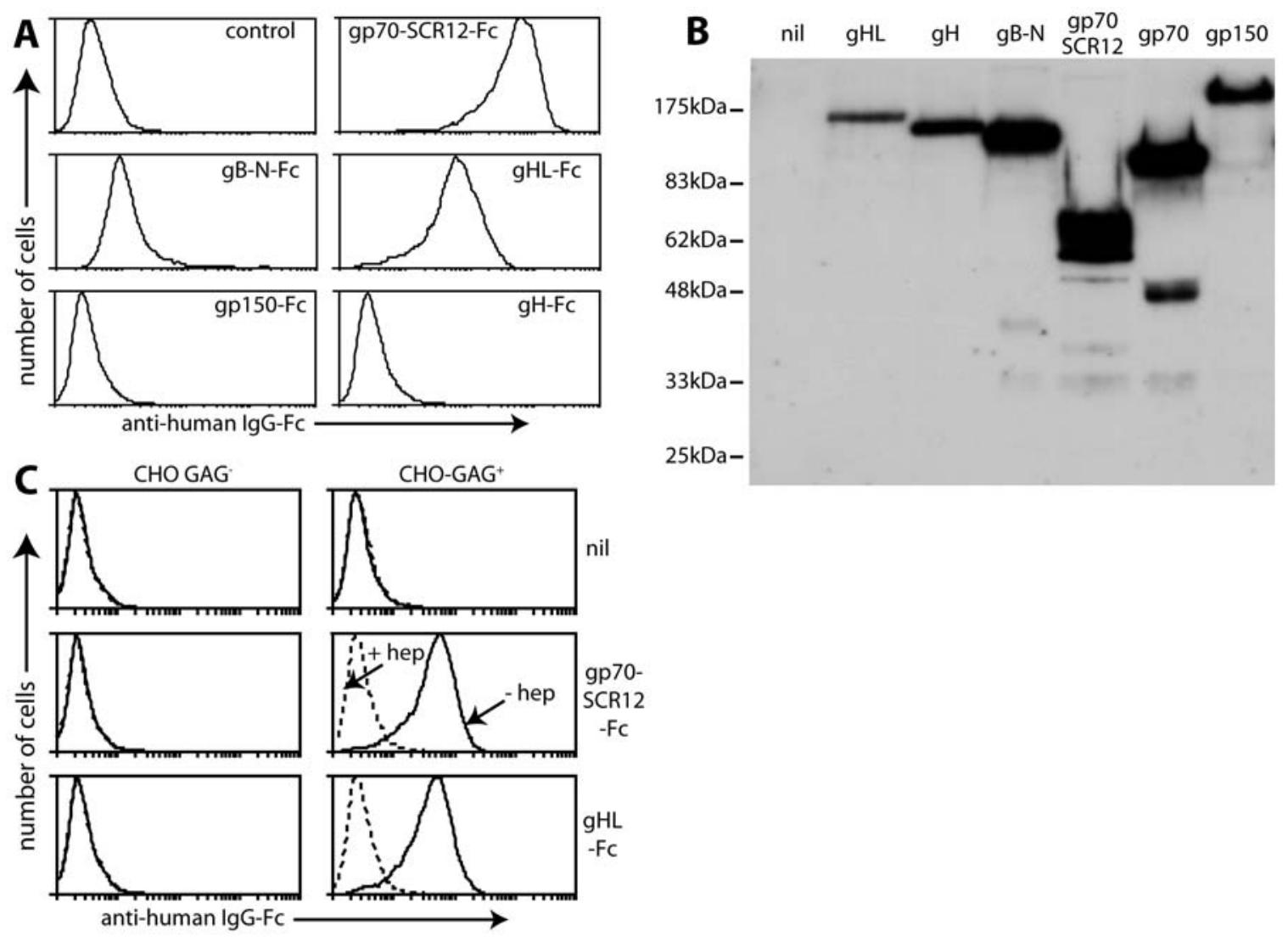

Figure 2. gHL-Fc binds to GAGs. A. Supernatants from 293T cells transfected with expression constructs for different lgG-Fc fusion proteins were

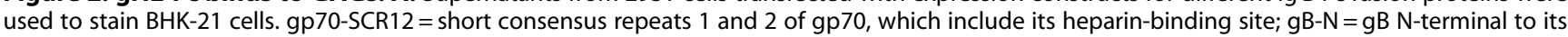
furin cleavage site, which incorporates its cell-binding domain. To retain GAG expression, the cells were plated onto Petri dishes $18 \mathrm{~h}$ before staining and then detached without trypsinization. Control = untransfected 293T cell supernatant plus secondary antibody. Equivalent data were obtained in 4 repeat experiments. B. The transfected cell supernatants from $\mathbf{A}$ were immunoblotted for their common human IgG-Fc domain. nil $=$ untransfected cell supernatant. gp70 $=\mathrm{Fc}$ fusion of the full-length protein, which was not used here. $\mathbf{C}_{\text {. }} \mathrm{GAG}^{+} \mathrm{CHO}$ cells or the GAG-deficient CHO-745 mutant $\left(\mathrm{GAG}^{-}\right)$were stained with $\mathrm{Fc}$ fusion proteins as indicated, either in the presence (dashed lines) or absence (solid lines) of $300 \mu \mathrm{g} / \mathrm{ml}$ heparin. nil = secondary antibody only. Equivalent data were obtained in 2 repeat experiments. doi:10.1371/journal.pone.0001669.g002

Coomassie staining (Fig. 3A) showed a weak $85 \mathrm{kDa}$ band in $\mathrm{gH}$-specific immunoprecipitates, which corresponds to $\mathrm{gH}[13]$. This band was not obvious in heparin-agarose precipitates due to background bands at the same molecular weight. We therefore immunoblotted the precipitates with an MuHV-4-immune rabbit serum, which (among other virion glycoproteins) recognizes $\mathrm{gH}$ [13] (Fig. 3B). This identified an $85 \mathrm{kDa}$ band precipitated by heparin-agarose from $\mathrm{gL}^{+}$but not $\mathrm{gL}^{-}$lysates. (The faint background band in the $\mathrm{gL}^{-}$lane has a slightly lower molecular weight.) The same band was immunoprecipitated from $\mathrm{gL}^{+}$and $\mathrm{gL}^{-}$lysates by a $\mathrm{gH}$-specific $\mathrm{mAb}$ and only from $\mathrm{gL}^{+}$virion lysates by a $\mathrm{gH} / \mathrm{gL}$-specific $\mathrm{mAb}$, confirming that it was $\mathrm{gH}$ (Fig. $3 \mathrm{~B}$ ). The $70 \mathrm{kDa}$ band precipitated from $\mathrm{gL}^{+}$and $\mathrm{gL}^{-}$lysates by heparinagarose corresponds to gp70 [2].

The immune serum more strikingly detected the characteristic bands of virion gB-a minor $120 \mathrm{kDa}$ full length form and its more abundant $65 \mathrm{kDa} \mathrm{N}$-terminal and $55 \mathrm{kDa}$ C-terminal cleavage products [18,21]-whenever the $85 \mathrm{kDa}$ band was present. The presence of $\mathrm{gB}$ was confirmed by immunoblotting the same precipitates with a gB-specific $\mathrm{mAb}$ (Fig. 3C). The precipitation of gB by heparin-agarose was initially puzzling, since we have previously shown that $\mathrm{gB}$ does not bind to GAGs [2]. Specifically, $\mathrm{gB}-\mathrm{N}-\mathrm{Fc}$ binding to cells is GAG-independent; heparin-agarose does not precipitate $\mathrm{gB}$ from Triton $\mathrm{X}-100$ virion lysates; and the "heparin-binding" motif of gB is buried rather than accessible in its crystal structure $[2,19]$-even allowing for $\mathrm{gB}$ conformation changes akin to those of the Vesicular stomatits virus glycoprotein $\mathrm{G}$ [22], it is hard to see how this motif could participate in GAG binding. However, $\mathrm{gB}$ precipitation from digitonin lysates by heparin-agarose was entirely consistent with $\mathrm{gH} / \mathrm{gL}$ binding to GAGs, since in digitonin $\mathrm{gB}$ remains attached to $\mathrm{gH} / \mathrm{gL}$ [6]. This is seen by $\mathrm{gB}$ being precipitated from $\mathrm{gL}^{+}$and $\mathrm{gL}^{-}$lysates by a $\mathrm{gH}$-specific $\mathrm{mAb}$ and just from $\mathrm{gL}^{+}$lysates by a $\mathrm{gH} / \mathrm{gL}$-specific $\mathrm{mAb}$ (Fig. 3B, 3C). The coprecipitated $\mathrm{gB}$ was more obvious than the precipitated $\mathrm{gH} / \mathrm{gL}$ in Fig. 3B simply because the MuHV-4-immune rabbit serum, which recognizes $\mathrm{gB}[18]$, immunoblots $\mathrm{gB}$ better than it immunoblots $\mathrm{gH}$.

\section{MAb blockade of GAG binding by $\mathrm{gHL}-\mathrm{Fc}$}

Further support for a physiologically relevant interaction between gH/gL and GAGs came from antibody blocking (Fig. 4). In Fig. 4A, mAb LT-6E8 specifically inhibited gp70-Fc binding, mAb 8F 10 specifically inhibited gHL-Fc binding and a $\mathrm{gB}$-specific $\mathrm{mAb}$ inhibited neither. The $\mathrm{gH} / \mathrm{gL}-$-specific $\mathrm{mAbs} 230-4 \mathrm{~A} 2$ and 230$5 \mathrm{~B} 2$ also completely blocked gHL-Fc binding. Several other gH/gLspecific $m A$ bs had partial effects, but multiple IgM, $\operatorname{IgG}_{2 a}, \operatorname{IgG}_{1}$ and $\mathrm{IgG}_{2 \mathrm{~b}}$ control $\mathrm{mAbs}$ failed to block either $\mathrm{F}_{\mathrm{c}}$ fusion protein (data not shown). Thus, the blocking was antigen-specific. 

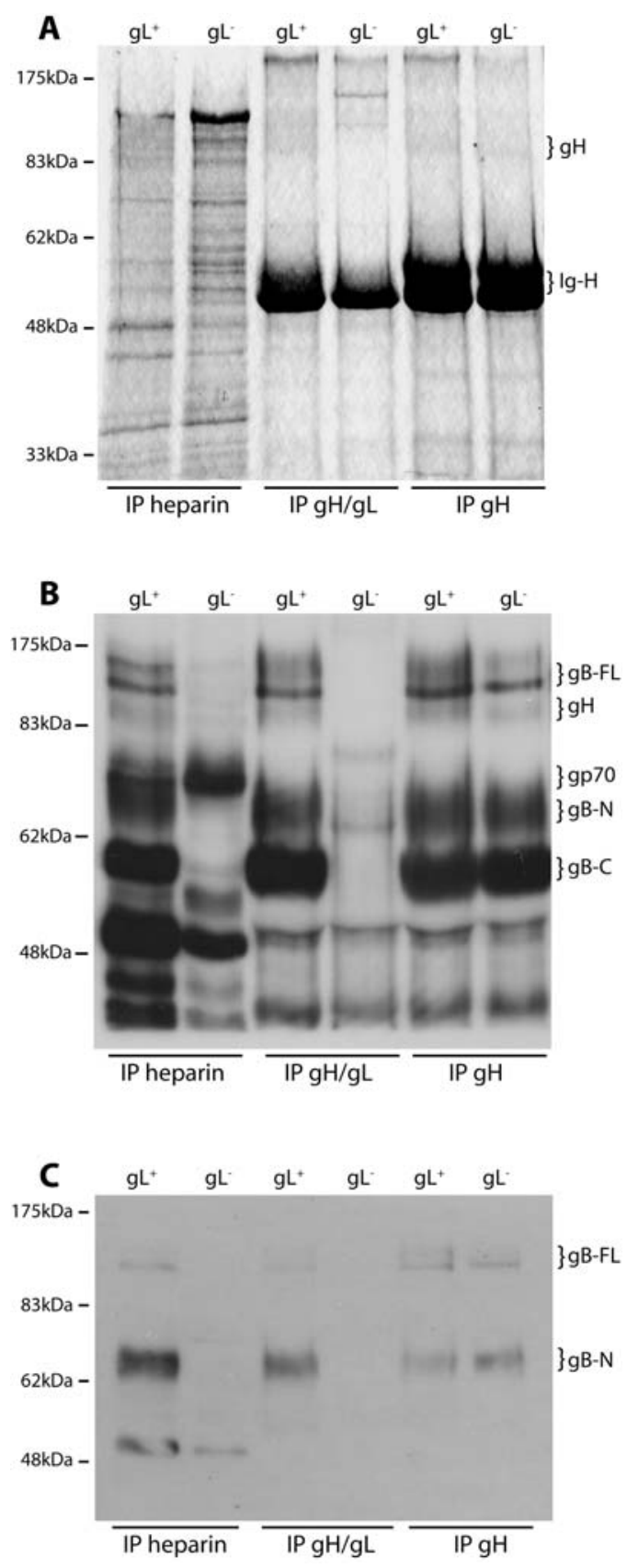

Figure 3. Virion $\mathbf{g H} / \mathbf{g L}$ binds to GAGs. A. Wild-type $\left(\mathrm{gL}^{+}\right)$and $\mathbf{g L}-$ deficient $\left(\mathrm{gL}^{-}\right)$virions were lysed in $1 \%$ digitonin, then immunoprecipitated with either heparin-agarose or protein A-sepharose plus mAb 7E5 ( $\mathrm{gH} / \mathrm{gL}$-specific) or $8 \mathrm{C} 1$ (which recognizes all forms of $\mathrm{gH}$ ). The washed precpitates were denatured, resolved by SDS-PAGE and visualized by Coomassie staining. The positions of $\mathrm{gH}(85 \mathrm{kDa})$ and $\mathrm{IgG}$ heavy chains $(\mathrm{lg}-\mathrm{H}, 50-55 \mathrm{kDa})$ are shown. The $\mathrm{gH}$ signal was weak but clearly visible by comparison with the $\mathrm{gL}^{-}$virion/gH/gL IP control. The data are from 1 of 2 equivalent experiments. B. The same precipitates as in A were immunoblotted with a MuHV-4-immune rabbit serum, which recognizes (among other virion proteins) gp70, gp 150, gB and gH. The MuHV-4 virion glycoproteins are readily distinguished by SDS-PAGE. The positions of $\mathrm{gH}$ (85 kDa), gp70, full-length $\mathrm{gB}$ (gB-FL, $120 \mathrm{kDa}$ ) and the $\mathrm{N}$ - and C-terminal gB cleavage products (gB-N, $65 \mathrm{kDa} ; \mathrm{gB}-\mathrm{C}, 55 \mathrm{kDa}$ ) are shown. The data are from 1 of 2 equivalent experiments. $\mathbf{C}$. The same precipitates were immunoblotted with $\mathrm{mAb} M \mathrm{MG}-10 \mathrm{C} 11$, which recognizes an epitope in gB$\mathrm{N}$. The gB-FL bands are faint because most virion $\mathrm{gB}$ is cleaved [18]. The identity of the $50 \mathrm{kDa}$ band in the heparin IP lanes is unclear. The only glycoprotein target of MG-10C11 is gB, but it is known to also recognize a $50 \mathrm{kDa}$ virion protein on immunoblots [21]. doi:10.1371/journal.pone.0001669.g003
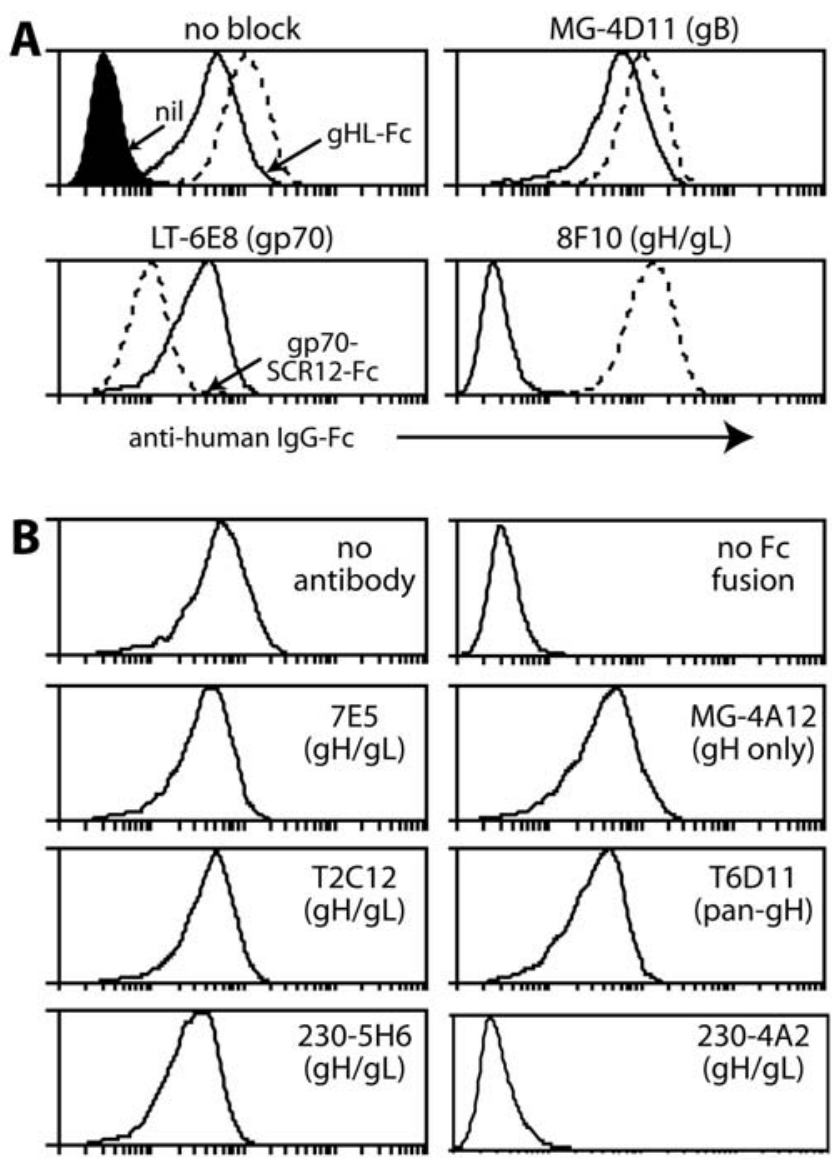

anti-human IgG-Fc
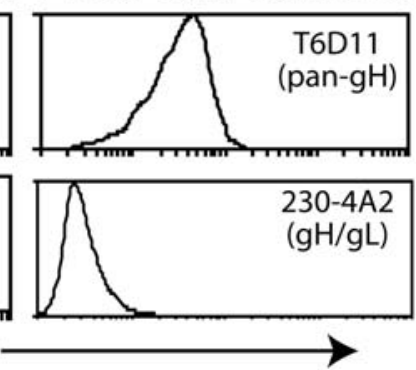

Figure 4. Inhibtion of Fc fusion protein binding by mAbs. A. Gp70-SCR12-Fc (dashed lines) $=$ SCR domains $1+2$ of gp70. gHL-Fc (solid lines) $=\mathrm{gH}$ fused to $\mathrm{C}$-terminal $\mathrm{gL}$. Each $\mathrm{Fc}$ fusion protein was preincubated or not with mAbs as indicated and then used to stain BHK-21 cells. The filled histogram (nil) shows secondary antibody only staining. Similar data were obtained in 2 repeat experiments. B. Further $\mathrm{gH}$-specific mAbs (see main text) were tested for their capacity to block gHL-Fc binding to BHK-21 cells.

doi:10.1371/journal.pone.0001669.g004

All our gH/gL-specific mAbs recognize conformational epitopes on MuHV-4-infected cells. Thus, their capacity to block GAG binding by $\mathrm{gHL}-\mathrm{Fc}$ argued that this involves native $\mathrm{gH} / \mathrm{gL}$ epitopes. The capacity of gH/gL-specific mAbs to block gHL-Fc binding did not particularly correlate with virion neutralization (Fig. 4B). For example, mAbs 7E5 and T2C12, which define the two major $\mathrm{gH} / \mathrm{gL}$ neutralization epitopes [13], both failed to inhibit gHL-Fc binding. And while the gHL-Fc blocking mAbs 8F10, 230-4A2 and 230-5B2 all have neutralizing activity, it was less than that of $7 \mathrm{E} 5$ or $\mathrm{T} 2 \mathrm{C} 12$ (data not shown). Indeed, gHL-Fc blocking does not necessarily explain the neutralization by $8 \mathrm{~F} 10,230-4 \mathrm{~A} 2$ or $230-5 \mathrm{~B} 2$; an inhibition of membrane fusion is also possible. MAb 230-5H6 defines a $\mathrm{gH} / \mathrm{gL}$ epitope that is normally protected by the $\mathrm{gB} \mathrm{N}$ terminus, but is a neutralization target when the $\mathrm{gB} \mathrm{N}$-terminus is deleted [20]. It failed to block gHL-Fc binding. Nor did gH-specific mAbs block binding-MG-4A12 provides a representative exampleconsistent with gH-Fc failing to bind GAGs (Fig. 1B).

\section{MAb blockade of cell binding by MuHV-4 virions}

The weak GAG binding of gp150 [2] seemed unlikely to compensate directly for a lack of $\mathrm{gH} / \mathrm{gL}$ or gp70. But gp70 and 
$\mathrm{gH} / \mathrm{gL}$ could potentially compensate for each-other, preventing antibodies specific for one or the other from blocking virion binding. This would explain why gp70 is a poor neutralization target and why $\mathrm{gH} / \mathrm{gL}$-specific neutralizing mAbs act mainly after binding [13]. Consistent with such an idea, synergistic neutralization was observed between mAbs LT-6E8 and 230-4A2 (Fig. 5A). LT-6E8 alone had little effect except at very high dose; 230-4A2 alone gave some neutralization, possibly by inhibiting infection post-binding; but LT-6E8 and 230-4A2 together were strongly neutralizing. We observed a similar synergistic blockade of virion binding (Fig. 5B, 5C): either mAb alone had much less effect than both combined.

The capacity of gp70 and gH/gL each to compensate for a loss of GAG binding by the other was confirmed with knockout viruses (Fig. 5D). gL-deficient MuHV-4 was much more potently neutralized than the wild-type by mAb LT-6E8; and gp70-deficient MuHV-4 was more potently neutralized than the wild-type by the gH/gL blocking mAbs 230-4A2 and 230-5B2. Thus, virions showed redundancy in GAG binding between gp70 and $\mathrm{gH} / \mathrm{gL}$.

\section{Neutralization directed against GAG binding in the absence of gp150}

Gp150 is a major determinant of MuHV-4 GAG dependence, since gp $150^{-}$viruses are much less GAG-dependent than the wildtype [1]. The main deficit of gp150 knockouts is poor virion release, presumably because their GAG-independent virions are recaptured onto the GAG-deficient surfaces of infected cells [1]. This phenotype implies that gp150 normally covers a cell-binding epitope. The protected epitope is unlikely to be on $\mathrm{gH} / \mathrm{gL}$ or gp70, since it binds a non-GAG ligand. Also, $\mathrm{gL}^{-}$gp $150^{-}$[6] and gp70- $\mathrm{gp} 150^{-}$mutants (data not shown) both retain the increased binding to GAG-deficient cells of the gp $150^{-}$mutant.

We tested whether the gp150-regulated binding could compensate for a lack of $\mathrm{gH} / \mathrm{gL}$ or gp70 binding by comparing the antibody-mediated blockade of $\mathrm{gp} 150^{+}$and $\mathrm{gp} 150^{-}$virions binding to $\mathrm{GAG}^{+}$and $\mathrm{GAG}^{-} \mathrm{CHO}$ cells (Fig. 6). For CHO $\mathrm{GAG}^{+}$cells, antibody had less effect on either binding or infection when gp150 was lacking (compare the wild-type and knockout viruses). As expected, antibody was poorly effective against either virus infecting $\mathrm{GAG}^{-} \mathrm{CHO}$ cells (where wild-type infectivity is anyway low). The modest reduction in infectivity with mAb 230$4 \mathrm{~A} 2$ presumably reflected a post-binding block of membrane fusion. The complexity of virus/cell interactions must be borne in mind when interpreting these data: $\mathrm{GAG}^{+}$and $\mathrm{GAG}^{-} \mathrm{CHO}$ cells may differ in more than GAG expression; high virion avidity may allow gp70 and gH/gL to bind other polyanions in some settings; and gp150 deficiency may have knock-on effects on other virion glycoproteins. But the results argued strongly that gp70 and $\mathrm{gH} /$ gL between them provide the initial MuHV-4 cell attachment, and showed that GAG-independent binding can supplant gp70 and $\mathrm{gH} / \mathrm{gL}$ only when gp150 is missing. GAG engagement by $\mathrm{gH} / \mathrm{gL}$ and gp70 must therefore normally precede gp150 displacement.

\section{Heparin inhibition of MuHV-4 infection}

The dual role of GAGs in MuHV-4 entry-binding to $\mathrm{gH} / \mathrm{gL}$ and gp70, and relieving the gp150 inhibition of GAG-independent binding-raised the question as to how soluble heparin inhibits infection. Heparin blocks wild-type MuHV-4 infection much better than that of a gp150 knockout [1]. But was the difference due to non-GAG binding rescuing gp150 knockouts, or to heparin blocking gp150 displacement rather than $\mathrm{gH} / \mathrm{gL} / \mathrm{gp} 70$ binding? To address this, we compared $\mathrm{GAG}^{+}$and $\mathrm{GAG}^{-} \mathrm{CHO}$ cell binding and infection by gp $150^{+}$and gp $150^{-}$MuHV-4 at different heparin concentrations (Fig. 7).
As before, each virus infected $\mathrm{GAG}^{+} \mathrm{CHO}$ cells to much the same level, and the gp150 knockout infected $\mathrm{GAG}^{-} \mathrm{CHO}$ cells much better than wild-type MuHV-4 did. Heparin also blocked wild-type MuHV-4 much better than the gp150 knockout for $\mathrm{GAG}^{+} \mathrm{CHO}$ cell infection and binding, consistent with the antibody blockade differences in Fig. 6. As expected, heparin had little effect on either virus binding to or infecting $\mathrm{GAG}^{-} \mathrm{CHO}$ cells. The key finding was that the binding and infection blocks for wild-type $\mathrm{MuHV}-4$ on $\mathrm{GAG}^{+} \mathrm{CHO}$ cells titrated out similarly. Thus, there was no evidence for heparin blocking a post-binding gp150 displacement better than the initial $\mathrm{gp} 70 / \mathrm{gH} / \mathrm{gL}$ cell binding. The data argued instead for a simple, heparin-mediated binding block from which gp $150^{-} \mathrm{MuHV}-4$ could be rescued by GAG-independent binding. The non-availability of this ligand to gp $150^{+}$MuHV-4 fitted with GAG-dependent cell binding preceding gp150 displacement.

\section{Discussion}

MuHV-4 infection is highly GAG-dependent. We previously identified gp150 as a key mediator of this dependence, in that disrupting gp150 makes infection GAG-independent $[1,2]$. The present data refine this model by showing that MuHV-4 has 2 GAG-binding proteins-gp70 and $\mathrm{gH} / \mathrm{gL}$-which act upstream of gp150. Gp70 and $\mathrm{gH} / \mathrm{gL}$ between them provide $\mathrm{MuHV}-4$ with its vital first cell contact. MuHV-4 GAG dependence is consequently twofold: first $\mathrm{gH} / \mathrm{gL}$ or gp70 must attach virions to cellular GAGs; then GAGs interact with gp150 to allow GAG-independent binding. We presume that gp150 displacement reveals an epitope on $\mathrm{gB}$, since this is the only MuHV-4 glycoprotein known to have a non-GAG ligand. Direct evidence for a $\mathrm{gB} / \mathrm{gp} 150$ interaction is lacking, but however $\mathrm{gB}$ is engaged, the different MuHV-4 GAG interactions are now seen to make a functionally coherent whole, combining efficient virion capture with down-stream binding initiated only at the cell surface.

Why does MuHV-4 have multiple GAG-binding proteins? The gp150/GAG interaction can be explained as triggering rather than adhesion, but this still leaves redundancy between gp70 and gH/gL. $\mathrm{gL}$ could have a particular role in gp150 displacement, since a $\mathrm{gL}$ deficiency somewhat reduces the virion gp150 content [6]. But $\mathrm{gL}^{-}$ virions show no qualitative difference in gp150 function, only a mild deficiency phenotype commensurate with their reduced gp150 content [6]. (Gp70 knockouts show no gp150 deficiency [2].) It seems more likely that $\mathrm{gH} / \mathrm{gL}$ GAG binding allows for the effects of gp70 cleavage. Immunoblots indicate that BHK-21 cell-derived virions shed the GAG binding domain from at least $50 \%$ of their gp70 [2]. This may be important for efficient virion release, or for other gp70 functions such as complement evasion [7]. It may also be cell typedependent [2]. If little gp70 were left uncleaved, GAG binding by $\mathrm{gH} / \mathrm{gL}$ would be vital for attachment.

MuHV-4 is similar in its GAG-dependence not only to other herpesviruses [23] but also to unrelated viruses [24] and other, more complex intracellular pathogens [25]. GAGs evidently provide a useful general way to attach to and infect host cells. The ubiquity of GAG expression must confer on GAG-binding virions a general stickiness that helps to keep them cell-associated. Both virions and GAGs are inherently repetitive, so high avidity will tend to make their interaction irreversible. This emphasizes the general problem faced by virions passing between hosts, that they must combine efficient release from one epithelial surface with efficient penetration of the next. The predominant localization of GAGs to basolateral rather than apical epithelial surfaces [26] would allow MuHV-4 reactivating from a latently infected B cell to engage GAGs and infect epithelial cells basolaterally, before 

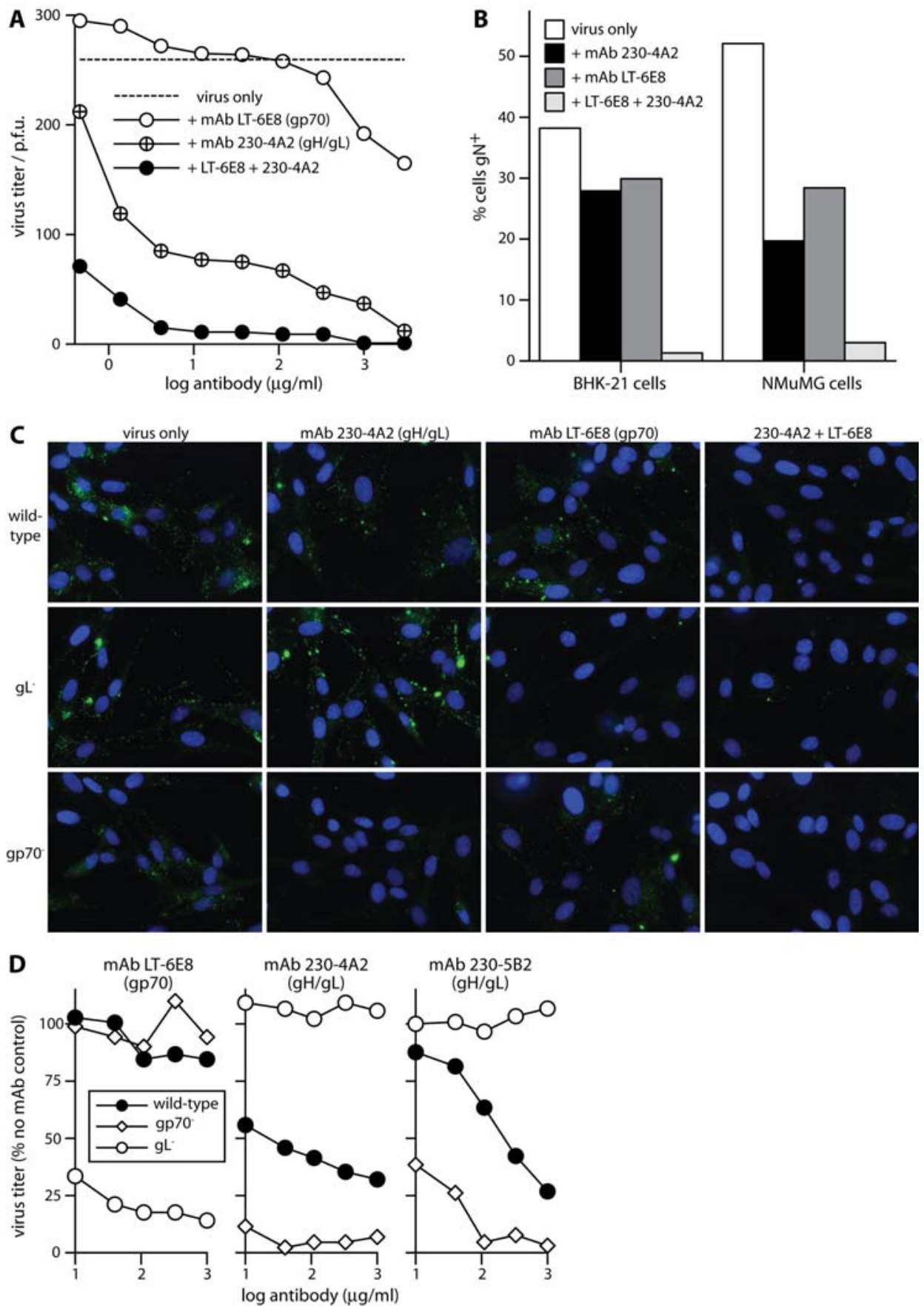

Figure 5. Inhibition of MuHV-4 infection by gp70-Fc and gHL-Fc blocking mAbs. A. Wild-type virions (200 p.f.u.) were incubated with mAbs as shown $\left(2 \mathrm{~h}, 37^{\circ} \mathrm{C}\right)$ then plaque-assayed on BHK-21 cells. We compared pairs of treatment arms by scoring (+ or -) for each antibody dilution whether the titer of a given treatment arm was more or less than the mean of both. We then performed an exact Chi-squared test on the comparisons. By this measure, mAb 230-4A2 but not mAb LT-6E8 gave significant neutralization, and 230-4A2 plus LT-6E8 was significantly better than 230-4A2 alone $(p<0.0001)$. Equivalent data were obtained in 2 further experiments. B. Wild-type virions were incubated with $\mathrm{mAbs}\left(2 \mathrm{~h}, 37^{\circ} \mathrm{C}\right.$, $1 \mu \mathrm{g} / 1000$ p.f.u.) then bound to either BHK-21 or NMuMG cells $\left(2 \mathrm{~h}, 37^{\circ} \mathrm{C}, 3\right.$ p.f.u./cell). Bound virions were detected by washing, fixing and permeabilizing the cells, then staining them for $\mathrm{gN}$ with $\mathrm{mAb} 3 \mathrm{~F} 7$. Secondary detection was with Alexa488-conjugated goat anti-mouse IgG pAb. This would have detected mAbs LT-6E8 and $230-4 \mathrm{~A} 2$ even if the $\mathrm{gN}$ epitope were masked. The cells were scored simply as positive or negative on staining. Each bar shows the \% positive of 10,000 cells, based on a gate where unexposed cells were $0 \%$ positive. The differences in binding between no $\mathrm{mAb}$ block/single $\mathrm{mAb}$ block, and between single $\mathrm{mAb}$ block/dual $\mathrm{mAb}$ block were highly significant $(\mathrm{p}<0.0001$ by Student's t test). Equivalent data were obtained in 1 further experiment. C. Wild-type, gp70-deficient or gL-deficient virions $\left(200\right.$ p.f.u.) were each incubated with $\mathrm{mAbs}\left(2 \mathrm{~h}, 37^{\circ} \mathrm{C}\right.$, $1 \mu \mathrm{g} / 1000$ p.f.u.), then with BHK-21 cells ( $2 \mathrm{~h}, 37^{\circ} \mathrm{C}, 3$ p.f.u./cell) as in B. The cells were then washed $\mathrm{x} 3$ in PBS, fixed and permeabilized, stained for gN with mAb 3 F7 (green), counterstained with DAPI (blue) and examined microscopically for virion uptake. As in B, the anti-mouse secondary antibody would also have detected bound 230-4A2 or LT-6E8, so we could be sure no virions were missed because mAb binding had masked gN. D. Wild-type, gp70-deficient or gL-deficient virions (200 p.f.u.) were each incubated with mAbs as shown $\left(2 \mathrm{~h}, 37^{\circ} \mathrm{C}\right)$ then plaque assayed on BHK-21 cells. $230-4 \mathrm{~A} 2$ and 230-5B2 both block gHL-Fc binding; LT-6E8 blocks gp70-Fc binding. Titers are plotted as \% of p.f.u. without mAb for each virus. We compared treatment arms by an exact Chi-squared test of the pairwise comparisons at each antibody dilution, as in $\mathbf{A}$. By this measure, mAb LT-6E8 neutralized the gL knockout but not the wild-type or gp70 knockout, and mAbs 230-4A2 and 230-5B2 neutralized the wild-type and gp70 knockout-the gp70 knockout significantly better than the wild-type-but not the gL knockout $(p<0.004)$. The data are from 1 of 5 equivalent experiments. doi:10.1371/journal.pone.0001669.g005 

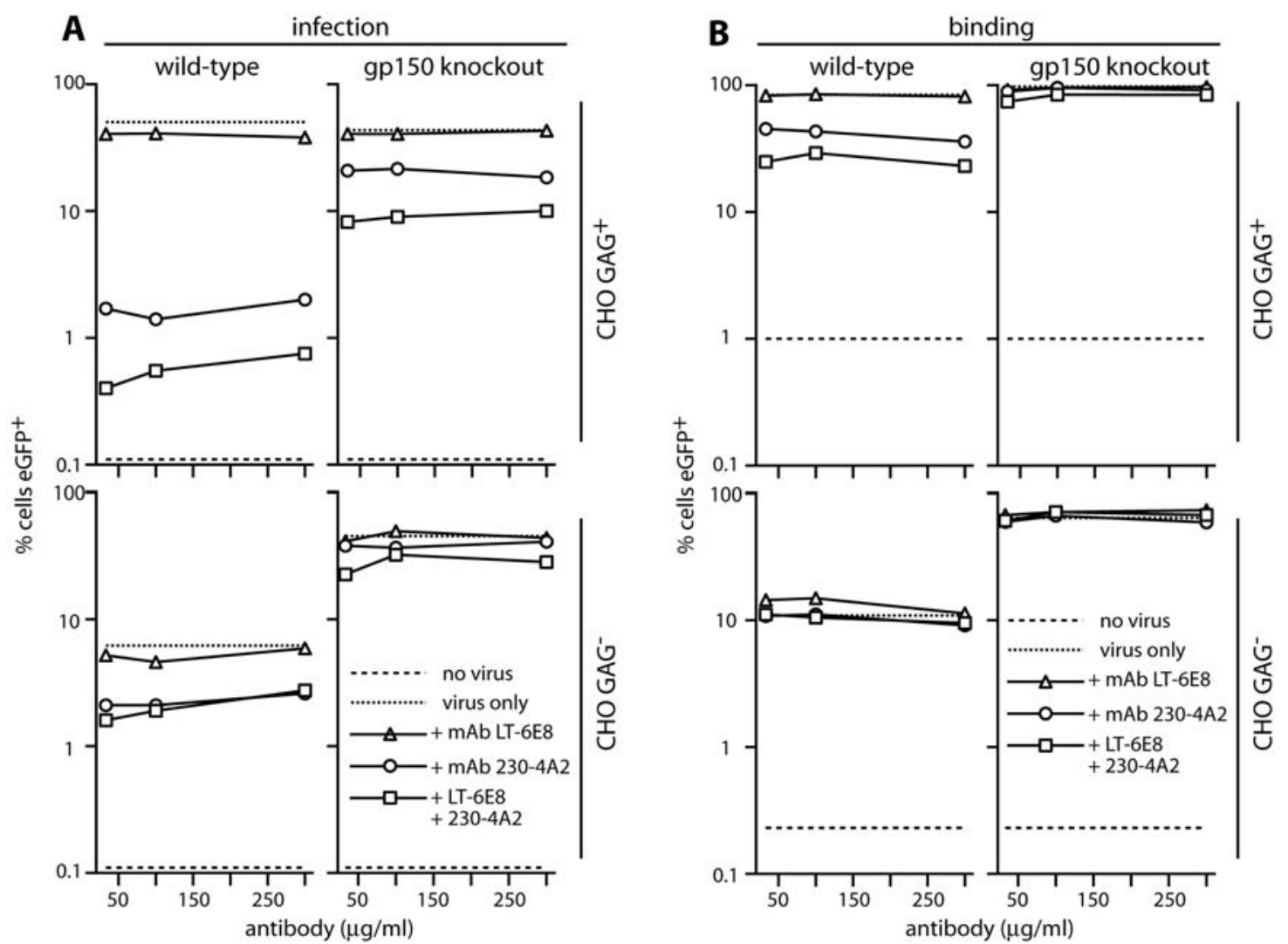

Figure 6. Gp150 deficiency alleviates an antibody-mediated block to GAG binding. A. EGFP-expressing wild-type or gp150 knockout virions were incubated with $\mathrm{mAbs}$ as shown, then used to infect $\mathrm{GAG}^{+}$and $\mathrm{GAG}^{-} \mathrm{CHO}$ cells. Infection was assayed $18 \mathrm{~h}$ later by flow cytometry of viral eGFP expression, counting the \% eGFP ${ }^{+}$cells in a gate where uninfected cells (no virus) were $<0.2 \%$ eGFP. A log scale is used to encompass the large differences in infection between gp $150^{+}$and gp $150^{-}$viruses and between $\mathrm{GAG}^{+}$and $\mathrm{GAG}^{-} \mathrm{CHO}$ cells. Each point represents 10,000 cells. Equivalent data were obtained in a repeat experiment. B. gM-eGFP versions of the same viruses, which have eGFP ${ }^{+}$virions, were incubated with $\mathrm{GAG}^{+}$and GAG ${ }^{-} \mathrm{CHO}$ cells $\left(2 \mathrm{~h}, 37^{\circ} \mathrm{C}\right)$ to allow binding/endocytosis. The cells were then washed $\mathrm{x} 3$ in PBS and assayed for eGFP uptake by flow cytometry. Each point represents 3,000 cells. Equivalent data were obtained in a repeat experiment. We compared viruses and cell types by taking the reduction in infectivity for each point of each of the 2 experiments (total $n=6$ ). We then compared the reductions using Student's test. This showed that $m A b$ 230-4A2 and the double antibody treatment both neutralized wild-type MuHV-4 significantly better than the gp150 knockout, and that neutralization of the wild-type was significantly better with $\mathrm{GAG}^{+} \mathrm{CHO}$ cells than with $\mathrm{GAG}^{-}(\mathrm{p}<0.01)$.

doi:10.1371/journal.pone.0001669.g006

being released apically for transmission. Reduced GAG expression on infected cells [1] and shedding of the gp70 GAG binding domain [2] would compensate for any local breakdown of the epithelial barrier. The GAG shedding that accompanies inflammation [27] could also help. But the GAG-dependent virions would then have to reach basolateral GAGs to infect new hosts. Mucosal sampling pathways such as M cell transcytosis [28] may therefore be important for primary MuHV-4 infection: moving virions from the apical to the basolateral epithelial surface and initiating infection from underneath. Understanding herpesvirus transmission and how to prevent it clearly require that we learn more about virion uptake. The two-fold GAG-dependence of MuHV-4 implies that its incoming virions somehow reach the basolateral epithelial surface.

\section{Materials and Methods}

\section{Viruses}

All viruses were derived from a cloned MuHV-4 BAC [29]. Unless indicated, the loxP-flanked BAC cassette, which includes a human cytomegalovirus IE1 promoter-driven eGFP expression cassette, was removed by virus passage through NIH-3T3-CRE cells [30]. Gp70-deficient [29], gL-deficient [12] and gp150-deficient [1] MuHV-4 BAC mutants have been described, as have derivatives with eGFP-tagged glycoprotein $\mathrm{M}$, which make fluorescent virions [21]. Virus stocks were grown and titered by plaque assay in BHK21 cells [1]. Infected cells and supernatants were sonicated after harvesting, cell debris was pelleted by low-speed centrifugation $(1000 \times g, 3 \mathrm{~min})$, and virions were recovered from supernatants by high speed centrifugation $(38000 \times g, 90 \mathrm{~min})$.

\section{Cells}

BHK-21 cells, NMuMG epithelial cells (American Type Culture Collection CRL-1636), CHO-K1 cells, the GAG-deficient CHO-745 mutant, NIH-3T3-CRE cells and 293T cells were all grown in Dulbecco's modified Eagle medium (Invitrogen, Paisley, U.K.) supplemented with $2 \mathrm{mM}$ glutamine, $100 \mathrm{U} / \mathrm{ml}$ penicillin, $100 \mu \mathrm{g} / \mathrm{ml}$ streptomycin and $10 \%$ fetal calf serum (PAA laboratories, Linz, Austria). Cells were transfected using Fugene6 (Roche Diagnostics Ltd., Lewes, U.K.).

\section{Plasmids}

A human $\mathrm{IgG}_{1}-\mathrm{F}_{\mathrm{c}}$ fusions of gp70 short consensus repeats $1+2$ has been described [2], as has an equivalent fusion of the $\mathrm{N}$ terminal half of $\mathrm{gB}$ [2]. The coding sequence for amino acid residues 1-450 of gp150 was PCR-amplified (Phusion DNA polymerase, New England Biolabs, Hitchin, U.K.) with 5' XbaI- 

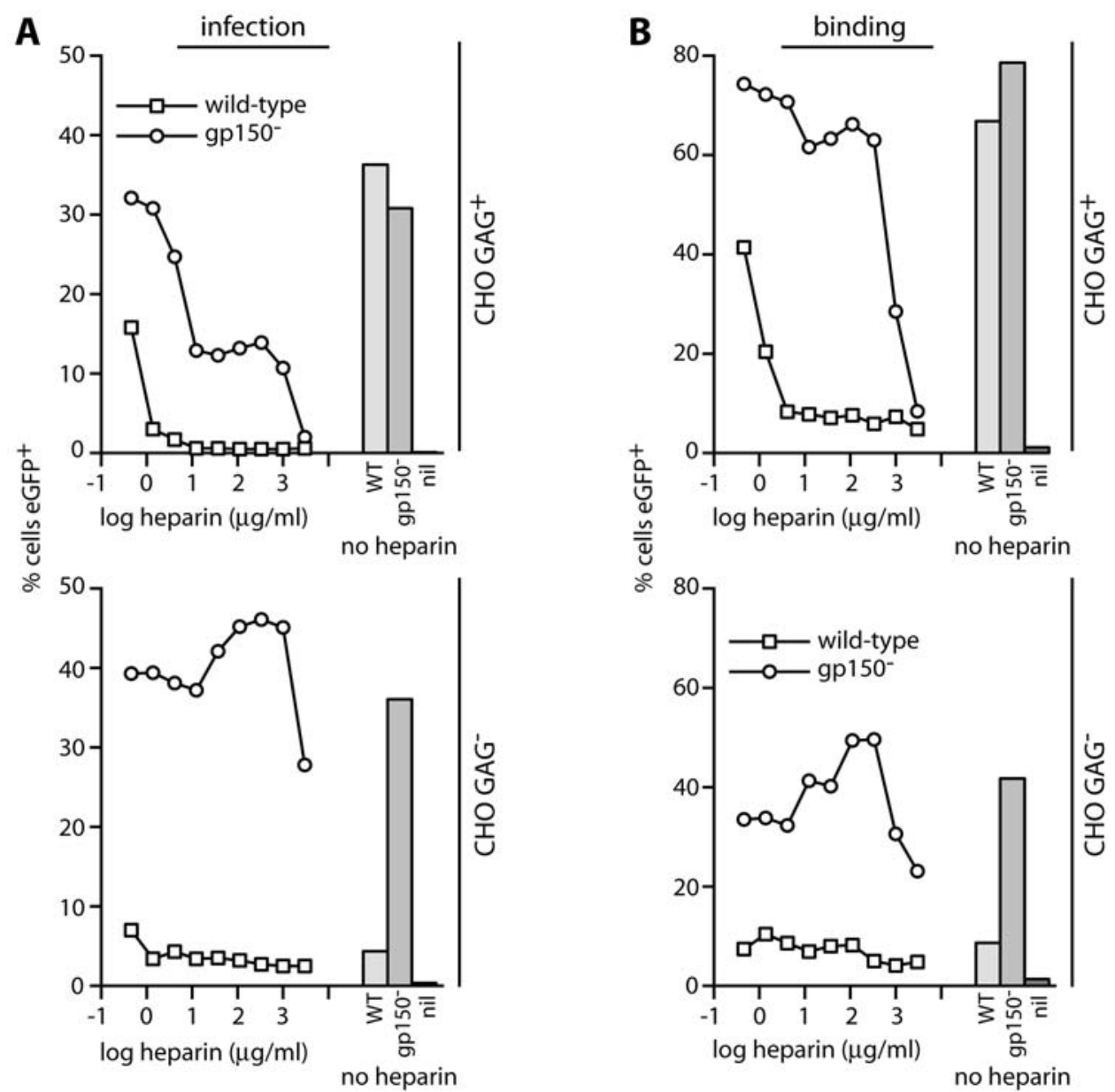

Figure 7. Comparison of MuHV-4 cell binding and infection in the presence of heparin. A. EGFP-expressing wild-type or gp150- virions were incubated with different heparin concentrations, then used to infect $\mathrm{GAG}^{+}$and $\mathrm{GAG}^{-} \mathrm{CHO}$ cells. Infection was assayed $18 \mathrm{~h}$ later by flow cytometry of viral eGFP expression, counting the \%eGFP ${ }^{+}$cells in a gate where uninfected cells (no virus) were $<0.2 \%$ eGFP ${ }^{+}$. Each point represents 10,000 cells. The bars show infection levels without heparin. nil $=$ no virus. Equivalent data were obtained in a repeat experiment. B. gM-eGFP ${ }^{+}$ versions of the same viruses were incubated with $\mathrm{GAG}^{+}$and $\mathrm{GAG}^{-} \mathrm{CHO}$ cells, with or without added heparin $\left(2 \mathrm{~h}, 37^{\circ} \mathrm{C}\right)$, then washed $\times 3$ in $\mathrm{PBS}$ and assayed for eGFP uptake by flow cytometry. Again, the bars show eGFP uptake without heparin, and nil = no virus. Equivalent data were obtained in a repeat experiment. The minor increases in $\mathrm{gp} 150^{-}$binding to and infection of $\mathrm{GAG}^{-} \mathrm{CHO}$ cells at low heparin dose were quite variable between experiments; the reductions, particularly in wild-type MuHV-4 infection of and binding to $\mathrm{GAG}^{+} \mathrm{CHO}$ cells, were not. doi:10.1371/journal.pone.0001669.g007

restricted and $3^{\prime} \mathcal{N}^{\prime} t \mathrm{I}$-restricted primers and cloned into $X b a \mathrm{I}$ and NotI sites upstream of a human $\mathrm{IgG}_{1}-\mathrm{Fc}_{\mathrm{C}}$ coding sequence as for gp70 and $\mathrm{gB}$ [2]. The $\mathrm{gH}$ extracellular domain was similarly fused to $\mathrm{IgG}_{1}-\mathrm{FC}_{\mathrm{C}}$ by PCR amplification of its extracellular domain (amino acid residues 1-703) with 5' AvrII-restricted and 3' NotI-restricted primers. gL missing most of its signal sequence was amplified with $5^{\prime}$ and $3^{\prime} \mathcal{N} o t \mathrm{I}$-restricted primers, and cloned in-frame into the $\mathcal{N} o t \mathrm{I}$ site between the $\mathrm{gH}$ extracellular domain and $\mathrm{IgG}_{1}-\mathrm{Fc}$, as with a GPIlinked version of the same fusion [17]. The full-length $\mathrm{gH}$ extracellular domain was PCR-amplified with EcoRI and XhoIrestricted primers and cloned into the $E c o \mathrm{RI} / X h_{0} \mathrm{I}$ sites of pcDNA3 (Invitrogen Corporation). Expression plasmids for RACE-mapped $\mathrm{gL}$, the gL ORF and gL-GPI have been described [13]. Fc fusion proteins were produced by transfecting the expression plasmids into $293 \mathrm{~T}$ cells using. Supernatants were collected after $48 \mathrm{~h}$.

\section{Monoclonal antibodies}

All mAbs described were generated from MuHV-4 carrier mice at least 6 months post-infection and selected for recognition of MuHV-4-infected BHK-21 cells without permeabilization. Thus, they define native epitopes on the virion or virus-infected cell surface. These mAbs were: 7E5, T2C12 [13], 230-5H6, 230-4A2, $8 \mathrm{~F} 10$ (all anti-gH/gL), 8C1 (recognizes both $\mathrm{gH}$ and gH/gL) [13], MG-4A12 (recognizes gH rather than $\mathrm{gH} / \mathrm{gL}$ ) [12], LT-6E8 (antigp70), MG-4D11 (anti-gB), MG-10C11 (anti-gB) [21], and 3F7 (anti-gN) [31]. MAb 230-5H6 is $\mathrm{IgG}_{1}$; MG-10C11 is IgM; 8C1 is $\mathrm{IgG}_{2 \mathrm{~b}}$; all the others are $\operatorname{IgG}_{2 \mathrm{a}}$.

\section{Immunoprecipitation and Immunoblotting}

Virions were lysed on ice for $45 \mathrm{~min}$ in $1 \%$ digitonin, $50 \mathrm{mM}$ TrisCl pH 7.4, $150 \mathrm{mM} \mathrm{NaCl}, 5 \mathrm{mM} \mathrm{MgCl}_{2}$ with Complete protease inhibitors (Roche Diagnostics). Insoluble debris was pelleted by centrifugation $(13000 \times g, 15 \mathrm{~min})$. The lysates were then incubated with either heparin-agarose beads (Sigma Chemical Co., Poole, U.K.) or mAbs plus protein A-sepharose. The beads were washed $\times 5$ in $0.1 \%$ digitonin and heated $\left(95^{\circ} \mathrm{C}\right.$, $5 \mathrm{~min}$ ) in Laemmli's buffer. The released proteins were then resolved by SDS-PAGE. For total protein detection, gels were fixed in $10 \%$ acetic acid $/ 50 \%$ methanol and stained with Coomassie R250. For immunoblotting, the proteins were 
transferred to PVDF membranes (Perbio Science, Tattenhall, U.K.). The membranes were blocked with $10 \%$ non-fat milk in PBS/0.1\% Tween-20, then incubated with the gB-specific mAb MG-10C11 or with an MHV-68-immune rabbit serum [32]. Bound antibody was detected with horseradish peroxidaseconjugated rabbit anti-mouse IgG pAb (Dako Cytomation, Ely, U.K.) or horseradish peroxidase-conjugated donkey anti-rabbit IgG pAb (APBiotech, Little Chalfont, U.K.), followed by washing in PBS/0.1\% Tween-20, development with ECL substrate (APBiotech) and exposure to X-ray film.

\section{Flow cytometry}

Cells exposed to HCMV IE1 $\mathrm{eGFP}^{+}$or gM-eGFP ${ }^{+} \mathrm{MuHV}-4$ were trypsinized and analyzed directly for green fluorescence. For protein binding, cells were incubated with human IgG-Fc fusion proteins or with MuHV-4 glycoprotein-specific mAbs $\left(1 \mathrm{~h}, 4^{\circ} \mathrm{C}\right)$, washed $\times 2$ in PBS, and then incubated with fluoresceinconjugated rabbit anti-mouse IgG pAb (Dako Cytomation) or phycoerythrin-conjugated goat anti-human IgG-Fc pAb (Sigma Chemical Co.). For total rather than cell surface glycoprotein detection, the cells were fixed in $2 \%$ paraformaldehyde $(30 \mathrm{~min}$,

\section{References}

1. de Lima BD, May JS, Stevenson PG (2004) Murine gammaherpesvirus 68 lacking gp150 shows defective virion release but establishes normal latency in vivo. J Virol 78: 5103-5112.

2. Gillet L, Adler H, Stevenson PG (2007) Glycosaminoglycan interactions in murine gammaherpesvirus-68 infection. PLoS ONE 2: e347.

3. Mark L, Lee WH, Spiller OB, Villoutreix BO, Blom AM (2006) The Kaposi's sarcoma-associated herpesvirus complement control protein $(\mathrm{KCP})$ binds to heparin and cell surfaces via positively charged amino acids in CCP1-2. Mol Immunol 43: 1665-1675.

4. Trybala E, Svennerholm B, Bergstrom T, Olofsson S, Jeansson S, et al. (1993) Herpes simplex virus type 1-induced hemagglutination: glycoprotein $\mathrm{C}$ mediates virus binding to erythrocyte surface heparan sulfate. J Virol 67: 1278-1285.

5. Blom AM, Mark L, Spiller OB (2007) Viral heparin-binding complement inhibitors-a recurring theme. Adv Exp Med Biol 598: 105-125.

6. Gillet L, Stevenson PG (2007) Evidence for a multiprotein gamma-2 herpesvirus entry complex. J Virol 81: 13082-13091.

7. Kapadia SB, Molina H, van Berkel V, Speck SH, Virgin HW (1999) Murine gammaherpesvirus 68 encodes a functional regulator of complement activation. J Virol 73: 7658-7670.

8. Gillet L, May JS, Colaco S, Stevenson PG (2007) The murine gammaherpesvirus-68 gp150 acts as an immunogenic decoy to limit virion neutralization. PLoS ONE 2: e705.

9. Shannon-Lowe CD, Neuhierl B, Baldwin G, Rickinson AB, Delecluse HJ (2006) Resting B cells as a transfer vehicle for Epstein-Barr virus infection of epithelial cells. Proc Natl Acad Sci USA 103: 7065-7070.

10. Turk SM, Jiang R, Chesnokova LS, Hutt-Fletcher LM (2006) Antibodies to gp350/220 enhance the ability of Epstein-Barr virus to infect epithelial cells. J Virol 80: 9628-9633.

11. Moore MD, DiScipio RG, Cooper NR, Nemerow GR (1989) Hydrodynamic, electron microscopic, and ligand-binding analysis of the Epstein-Barr virus/ C3dg receptor (CR2). J Biol Chem 264: 20576-20582.

12. Gillet L, May JS, Colaco S, Stevenson PG (2007) Glycoprotein L disruption reveals 2 functional forms of the murine gammaherpesvirus- 68 glycoprotein $\mathrm{H}$. J Virol 81: 280-291

13. Gill MB, Gillet L, Colaco S, May JS, de Lima BD, et al. (2006) Murine gammaherpesvirus-68 glycoprotein H-glycoprotein L complex is a major target for neutralizing monoclonal antibodies. J Gen Virol 87: 1465-1475.

14. Hutchinson L, Browne H, Wargent V, Davis-Poynter N, Primorac S, et al. (1992) A novel herpes simplex virus glycoprotein, $\mathrm{gL}$, forms a complex with glycoprotein $\mathrm{H}(\mathrm{gH})$ and affects normal folding and surface expression of $\mathrm{gH}$. J Virol 66: 2240-2250.

15. Kaye JF, Gompels UA, Minson AC (1992) Glycoprotein H of human cytomegalovirus (HCMV) forms a stable complex with the HCMV UL115 gene product. J Gen Virol 73: 2693-2698. $23^{\circ} \mathrm{C}$ ) and permeabilized with $0.1 \%$ saponin before staining. All cells were washed $\times 2$ in PBS before analysis on a FACS Calibur (BD Biosciences, Oxford, U.K.)

\section{Immunofluorescence}

BHK-21 cells exposed to MuHV-4, washed with PBS to remove unbound virions, fixed in $4 \%$ paraformaldehyde (room temperature, $30 \mathrm{~min}$ ), permeabilized with $0.1 \%$ Triton X-100, stained for gN with mAb 3 F7 plus Alexa 488-conjugated goat anti-mouse IgG $\mathrm{pAb}$, washed $\times 2$, counterstained with DAPI and visualised with an Olympus microscope plus Retiga 4000R camera line (Qimaging, Burnaby, Canada).

\section{Acknowledgments}

We thank Janet May for outstanding technical support.

\section{Author Contributions}

Conceived and designed the experiments: PS LG. Performed the experiments: PS SG LG. Analyzed the data: PS LG. Wrote the paper: PS.

16. Parry C, Bell S, Minson T, Browne H (2005) Herpes simplex virus type 1 glycoprotein $\mathrm{H}$ binds to alphavbeta3 integrins. J Gen Virol 86: 7-10.

17. Gillet L, May JS, Stevenson PG (2007) Post-exposure vaccination improves gammaherpesvirus neutralization. PLoS ONE 2: e899.

18. Lopes FB, Colaco S, May JS, Stevenson PG (2004) Characterization of the MHV-68 glycoprotein B. J Virol 78: 13370-13375.

19. Heldwein EE, Lou H, Bender FC, Cohen GH, Eisenberg RJ, et al. (2006) Crystal structure of glycoprotein B from herpes simplex virus 1. Science 313: 217-220.

20. Gillet L, Stevenson PG (2007) Antibody evasion by the N terminus of murid herpesvirus-4 glycoprotein B. EMBO J 26: 5131-5142.

21. Gillet L, Gill MB, Colaco S, Smith CM, Stevenson PG (2006) The murine gammaherpesvirus-68 glycoprotein $\mathrm{B}$ presents a difficult neutralization target to monoclonal antibodies derived from infected mice. J Gen Virol 87: 3515-3527.

22. Roche S, Rey FA, Gaudin Y, Bressanelli S (2007) Structure of the prefusion form of the vesicular stomatitis virus glycoprotein G. Science 315: 843-848.

23. Shukla D, Spear PG (2001) Herpesviruses and heparan sulfate: an intimate relationship in aid of viral entry. J Clin Invest 108: 503-510.

24. Spillmann D (2001) Heparan sulfate: anchor for viral intruders? Biochimie 83: 811-817.

25. Wadström T, Ljungh A (1999) Glycosaminoglycan-binding microbial proteins in tissue adhesion and invasion: key events in microbial pathogenicity. J Med Microbiol 48: 223-233.

26. Bernfield M, Kokenyesi R, Kato M, Hinkes MT, Spring J, et al. (1992) Biology of the syndecans: a family of transmembrane heparan sulfate proteoglycans. Annu Rev Cell Biol 8: 365-393.

27. Fitzgerald ML, Wang Z, Park PW, Murphy G, Bernfield M (2000) Shedding of syndecan- 1 and -4 ectodomains is regulated by multiple signaling pathways and mediated by a TIMP-3-sensitive metalloproteinase. J Cell Biol 148: 811-824.

28. Kraehenbuhl JP, Neutra MR (2000) Epithelial M cells: differentiation and function. Annu Rev Cell Dev Biol 16: 301-332.

29. Adler H, Messerle M, Wagner M, Koszinowski UH (2000) Cloning and mutagenesis of the murine gammaherpesvirus 68 genome as an infectious bacterial artificial chromosome. J Virol 74: 6964-6974.

30. Stevenson PG, May JS, Smith XG, Marques S, Adler H, et al. (2002) K3mediated evasion of CD8(+) T cells aids amplification of a latent gammaherpesvirus. Nat Immunol 3: 733-740.

31. May JS, Colaco S, Stevenson PG (2005) Glycoprotein M is an essential lytic replication protein of the murine gammaherpesvirus 68. J Virol 79: 3459-3467.

32. Sunil-Chandra NP, Efstathiou S, Arno J, Nash AA (1992) Virological and pathological features of mice infected with murine gamma-herpesvirus 68. J Gen Virol 73: 2347-2356 